\title{
The relationship between HRM practices and the service performance of student interns: Industry perspective
}

\author{
C-S. Lee, C-W. Chao* and H-I Chen \\ Department of Restaurant, Hotel and Institutional Management, Fu-Jen Catholic University, Taipei, Taiwan \\ Department of Urban Planning, National Cheng Kung University, Tainan, Taiwan \\ Assistant professor, Department of Applied Science of Living, Chinese Culture University, Taipei, Taiwan \\ *To whom all correspondence should be addressed \\ weverchao@gmail.com
}

\begin{abstract}
This study aims to examine the relationship between human resource management (HRM) practices and the service performance of student interns. Data were collected using a questionnaire survey that was designed to capture the perceptions of human resource managers and internship supervisors from international tourist hotels in Taiwan. The structural equation model (SEM) was used as a framework for the data analysis. The findings indicate that the service performance of student interns was greatly affected by HRM practices, including recruitment and selection, rewarding quality, and retention. The implications of this study offer preliminary insights into the industry-academia co-operation that aims to manage total quality initiatives in the hotel industry and achieve the goals of hospitality higher education. The study lays the groundwork for the development of HRM practices for student interns to cope with the changing flexible labour structure in the hotel industry.
\end{abstract}

\section{Introduction}

Over the past decade, many developing countries in the Asia Pacific region (e.g., mainland China, Hong Kong, Macao, Malaysia, Thailand, etc.) transitioned from a secondary to a tertiary industry. The demand for a service workforce has led many academic institutions to develop hospitalityrelated programs. To facilitate hospitality students in the transition from school to the work environment, hospitality management programs within colleges and universities usually require students to participate in industry internship before graduation. The relationship between international hotels and higher education depends on the needs of students for internship credits and those of hotels for talented workers. The student interns have emerged with status and hospitality higher education backgrounds that will rival original flexible labour market dominance. The increasing proportion of student interns in the hotel industry inevitably results in many management-related initiatives.

In the past, many scholars have suggested that HRM practices have a positive effect on the organisational performance and service quality offered by the hotel industry (Jago \& Deery, 2004; Lucas, Marinova, Kucerova \& Vetrokova, 2004). However, previous studies have mainly focused on full-time employees, and research examining the relationship between HRM practices and the performance of hospitality student interns has been very limited. Generally speaking, student interns stay in a hotel for a semester (or an extra year) during their four years of study. From initial recruiting and selecting suitable student interns to retaining them as full-time employees, the HRM practices of hotels play an important role for these potential employees. Additionally, service quality depends heavily on the effectiveness with which front-line employees interact with customers (Sheng \& Lin, 2004). As important service providers, student interns often function in highly visible positions (for example, as waiters or front desk personnel) that require them to interact with guests. In a total quality management (TQM) effort, all members of an organisation participate in improving processes, products, services, and the culture in which they work (Ingelssona, Erikssona \& Liljaa, 2012). For these reasons, it is important to conduct research on the hotel industry with a particular emphasis on the relationship between HRM practices and student interns. Furthermore, the service performance of employees is often measured by the employees themselves or by customers. Due to the difficulty encountered in data collection, research conducted from the industry perspective is very limited. TQM functions on the premise that the quality of products and processes is the responsibility of everyone who is involved with the creation or consumption of the products or services. Measurements of HRM practices and service performance at the marginal level could provide a more objective representation of the current situation. Considering the change in workforce structure and the philosophy of TQM for continuously improving the quality of products and processes, this study emphasized the relation between HRM practices and the service performance of student interns. In this endeavour, industry practitioners will be able to apply initial insight in the management of customer relations and increase service quality. Hospitality educators may also incorporate HRM practices from hotel industry practitioners for developing quality hospitality talent. Accordingly, the objectives of this study were as follows: 
- to test the full model of HRM practices and service performance by using a structural equation model (SEM); and

- to examine the effects of HRM practices on the service performance of student interns.

\section{Literature review}

\section{Higher education hospitality internship}

Hospitality education emphasises the acquisition of practical experience outside of the classroom. Kanji and Tambi (1999) suggested that quality management is a central aspect of higher education institutions. Society views higher education institutions as excellent organisations made up of excellent people. Therefore, institutions with hospitality academic programs usually incorporate experiential learning into the curriculum to ensure that hospitality students are equipped with practical hospitality skills before graduation. Although experiential learning models come in different forms (industrial experience, industrial placement, supervised work experience, and internships), they tend to follow a similar pattern.

An industry internship is a common experiential learning model in which students are given a specific learning goal. McMahon and Quinn (1995) described internships as a "supervised work experience (SWE)" and noted that, instead of working alone in the industry, student interns work under special guidelines and receive special attention during their internships. In addition, internships are carefully monitored and planned with respect to academic accreditation. Currently, hospitality academic institutions have developed various internship programs. Some industry internships are conducted part-time over the course of a four-year program, which could mean interning for a few days each week for a few weeks during the year (usually during summer or winter vacation), or perhaps after school hours. Long-term industry internships usually include an extra year (or semester) of work experience at some point during a student's four years of study. Generally speaking, the wage rate for student interns is fixed and determined by an internship contract. Some internship organisations pay students on a permanentemployee basis or on a part-time basis; some interns even work without pay. To ensure that the quality of industry internships is maintained, hospitality higher education programs usually restrict student internship placements to international hotels. These hotels, with high standards of infrastructure, facilities, software, and services, have a high degree of departmentalisation and professional management systems. Moreover, internship placements in international hotels can provide students with an efficient experiential learning platform.

\section{The relationship between student interns and international hotels}

Kusluvan and Kusluvan (2000) indicated the importance of internships in hospitality programs, which establish a rewarding tripartite relationship among the student, the academic institution, and the hospitality industry. The basic principles of the TQM philosophy are to satisfy the customer, satisfy the supplier, and continuously improve processes. In the past, Kanji and Tambi (1999) suggested the customer groups of higher education while discussed TQM in UK higher education institutions. Figure 1 explains the relation between student interns and internship organisation. Student interns provide a workforce to fill the frontline requirements of international hotels. Simultaneously, student interns are internal customers that take advantage of the resources of international hotels to develop practical skills and experience. Managers or supervisors in the international hotels are the main consumers of the talents and abilities that educators impart to students. They also offer student interns vocational knowledge and technical training. Industry internships are therefore considered win-win situations in which students integrate their theoretical knowledge with the practical experiences gained through experiential learning, while international hotels gain access to a stable and well-trained workforce. Human resource planning in the hotel industry is challenging due to a fluctuating environment that makes the prediction of supply and demand difficult. Industry internships based on hospitality higher education enable international hotels to plan workforce employment in advance. By continuously improving the industry internship experience, internship employment can be regarded as a strategic human resource planning approach for international hotels to achieve the philosophy of TQM. Lucas (2004) also showed that the use of a student workforce has become a key strategic approach to human resource planning.

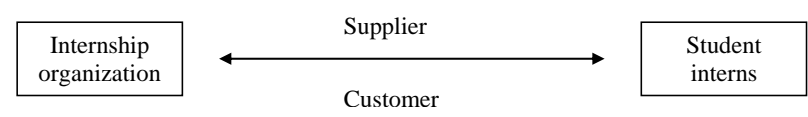

\section{Figure 1: Relationship between international organization and student interns}

\section{TQM-based HRM practices}

HRM policies, processes, and approaches designed to develop human potential and meet organisational goals have been broadly implemented in the hotel industry. HRM practices based on TQM concepts must be built on the presumption of employee and management dedication to quality and customer satisfaction. Previous studies have demonstrated the importance of HRM policies essential to the successful implementation of TQM, concentrating on the adaptation of HRM practices to underpin the development of the necessary motivation, attitudes and the competencies required for quality management (Wilkinson, Redman, Snape \& Marchington, 1998). While different approaches to HRM have been debated regarding the goal of "best fit" vs. "best practice" for organisations, Babu, Naresh and Kumar (2011) suggested the role of HRM in implementing and maintaining a TQM process whereby HR managers are responsible for recruiting high-quality employees, providing continuous training and development of those employees, and creating and maintaining reward systems. Nickson (2007) also suggested that attracting, maintaining, and 
developing a workforce are essential to the successful accomplishment of human resource objectives in the tourism and hospitality industry. Based on the research discussed above, the current study selected 'recruitment and selection', 'training and development', 'rewarding quality', and 'retention' as the four basic HRM practices representing general human resource objectives.

\section{The relationship between HRM practices and service performance}

The service performance of employees is reflected in their behaviour in serving and helping customers (Liao \& Chuang, 2004). An employee's service performance positively affects customer satisfaction (Hansen, Sandvik \& Selnes, 2003), which is the main focus of TQM through fundamental management techniques and a disciplined approach focused on continuous process improvement. Ugboro and Obeng (2000) also concluded that TQM is an approach used in directing organisational efforts toward the goal of customer satisfaction. The studies related to HRM on the service performance of employees are well documented in the TQM field. Sureshchandar, Rajendran and Anantharaman (2001) suggested that it is vital for service organisations to look upon HRM as a source of competitive advantage. They further identified HRM as a critical dimension of total quality service for effective implementation of quality management in service organisations. The role of TQM in building customer relationships lies on ensuring that the quality strives to satisfy its internal customer and thereby satisfy the external customer. Only if the employers treat their employees as precious resources would the employees treat their customers as valuable (Sureshchandar et al., 2001). A similar perspective was the people-centred HRM practices suggested by Dahlgaard-Park (2012) that organisations have to make efforts to achieve a deeper understanding of human nature in regard to the uniqueness, needs, and drivers of individuals and try to incorporate that information into organisational activities. Thus, efforts to promote the service performance of employees should be based on a TQM human resource development approach, with particular emphasis on student interns.

\section{Methods}

The purpose of this study was to test the full model of HRM practices and service performance by using a structural equation model. Further, the study examined the effect of HRM practices on the service performance of student interns in international hotels. Our research model consisted of a measurement model and a causal structural model. The former specifies links between latent constructs and their corresponding indicator variables, while the latter specifies causal relationships between the latent constructs themselves. Thus, structural equation modelling is one of the most applicable methods for examining our theory. SEM is a multivariate technique combining multiple regression and factor analysis to simultaneously estimate a series of interrelated dependence relationships. This approach allows researchers to test the full model of HRM practices and service performance by using several latent variables and multiple indicators. Furthermore, the researchers performed multiple regression analyses to examine the effect of HRM practices on the service performance of each student intern. Four HRM practices, including recruitment and selection, training and development, rewarding quality, and retention, are used as the predictor variables. The service performance, including prompt service, service attitudes, provision of information, and competency were used as the dependent variables. A total of four multiple regressions were conducted: (1) the effect of HRM practices on the prompt service delivery of student interns; (2) the effect of HRM practices on the service attitudes of student interns; (3) the effect of HRM practices on the provision of information by student interns; and (4) the effect of HRM practices on the competency of student interns.

The researchers used a questionnaire survey to collect empirical data for use in the current study. The questions in the survey were based on information obtained from reviewing the existing literature, and the questionnaire was pre-tested and revised. The questionnaire was designed to measure HRM practices, including recruitment and selection, training and development, rewarding quality, and retention. Additionally, the questionnaire used in this study to measure service performance was built upon previous research (Liao \& Chuang, 2004), which includes the areas of prompt service, service attitudes, provision of information, and competency. The measurement model of HRM practices hypothesises that the HRM practices of hotels constitute an exogenous latent variable that can be represented by four endogenous measured variables: recruitment and selection, training and development, rewarding quality, and retention. The measurement model of service performance used here hypothesises that the service performance of student interns is an exogenous latent variable that affects four endogenous latent variables, i.e., prompt service, service attitude, the provision of information, and competency.

The researchers then conducted purposive sampling to select managerial-level employees who were involved with industry internships and had contact with student interns in international hotels as candidate samples. In keeping with the research purpose of this study, managers and assistant managers of human resource departments comprised one segment of the survey of participants with experience managing interns. Directors, mangers, assistant managers, junior managers, captains, and headwaiters of food and beverage departments and catering departments comprised another segment of the survey of participants with experience in the supervision of student interns. Initially, the researchers mailed a letter to the chief manager of each international hotel that offered an internship program. The letter explained our research purpose and asked the chief manager to recommend suitable candidates for data collection. After collecting and identifying the sample list, we mailed an invitation letter to the desired participants and asked for their agreement. Then, we personally visited the respondents to show our sincerity, increase the response rate, and assure accuracy of the data collection. The 
respondents were asked to indicate the perceived importance of each HRM practice via a five-point Likert scale, from 'least important $(=1)$ ' to 'most important $(=5)$ '. Similarly, participants were also asked to rate the perceived service performance for each attribute using a five-point Likert scale, which in this case ranged from 'strongly disagree $(=1)$ ' to 'strongly agree $(=5)$ '. The survey was conducted from April to May 2010 in Taiwan.

\section{Results}

A total of 34 international tourist hotels agreed to participate in our data collection. Three hundred questionnaires were distributed and yielded 276 usable surveys. The valid response rate was $92 \%$. The respondent demographics are shown in Table 1.

Table 1: Respondent demographics $(n=276)$

\begin{tabular}{|c|c|c|}
\hline Item & $\mathrm{N}$ & $(\%)$ \\
\hline \multicolumn{3}{|l|}{ Gender } \\
\hline Male & 96 & 34.8 \\
\hline Female & 180 & 65.2 \\
\hline \multicolumn{3}{|l|}{ Age } \\
\hline Under 24 & 12 & 4.3 \\
\hline $25 \sim 34$ & 45 & 16.3 \\
\hline $35 \sim 44$ & 108 & 39.1 \\
\hline $45 \sim 54$ & 87 & 31.5 \\
\hline 55 or older & 24 & 8.7 \\
\hline \multicolumn{3}{|l|}{ Marital status } \\
\hline Married & 206 & 74.6 \\
\hline Single & 70 & 25.4 \\
\hline \multicolumn{3}{|l|}{ Education } \\
\hline High school & 101 & 36.6 \\
\hline College & 127 & 46.0 \\
\hline Graduate & 45 & 16.3 \\
\hline Doctoral & 3 & 1.1 \\
\hline \multicolumn{3}{|l|}{ Position } \\
\hline Human resource department & 52 & 18.8 \\
\hline Manager & 24 & 8.7 \\
\hline Assistant manager & 28 & 10.1 \\
\hline $\begin{array}{l}\text { Food and beverage } \\
\text { department }\end{array}$ & 145 & 52.5 \\
\hline Directors & 9 & 3.3 \\
\hline Manager & 15 & 5.4 \\
\hline Assistant manager & 23 & 8.3 \\
\hline Junior manager & 21 & 7.6 \\
\hline Captain & 35 & 12.7 \\
\hline Headwaiter & 42 & 15.2 \\
\hline Catering department & 79 & 28.6 \\
\hline Directors & 4 & 1.4 \\
\hline Manager & 10 & 3.6 \\
\hline Assistant manager & 12 & 4.3 \\
\hline Junior manager & 10 & 3.6 \\
\hline Captain & 21 & 7.6 \\
\hline Headwaiter & 22 & 8.0 \\
\hline
\end{tabular}

\section{SEM analysis}

Following the measurement model, the researchers conducted confirmatory factor analysis to measure the properties of the scales. The estimation of variables in this study was tested using maximum likelihood methods to determine whether the model fit the structural equation models. According to Anderson and Gerbing (1988), confirmatory measurement models should be evaluated before measurement and structural equation models are examined simultaneously. Therefore, the researchers analysed each construct in the model separately before testing the measurement model overall. Cronbach's alpha was used to assess the internal consistency of the proposed constructs. Because an item having a coefficient alpha below 0.30 is invalid, it is recommended that those items be deleted from further analysis (Joreskog, 1993). The results of the measurement model indicate that all constructs are greater than 0.7 , and thus, the constructs were considered reliable. To assess the model fit, the researchers applied six measures: chi square (evaluated using $\chi 2 /$ d.f.), goodness of fit index (GFI), root mean square error (RMR), normed fit index (NFI), adjusted goodness of fit index (AGFI), and comparative fit index (CFI). A $\chi^{2}$ value relative to the degree of freedom is a measure of overall fit of the model to the data. A significant $\chi 2$ value indicates that the observed and estimated variance-covariance matrices differ, whereas a non-significant $\chi 2$ value suggests that there is no significant difference and the model is accepted in absolute fit sense. In this study, the alpha level was taken to be 0.05 . In an attempt to make the model less dependent on sample size, the relative $\chi 2$ value is the chi square fit index divided by the degrees of freedom. $\chi 2 /$ d.f. in the range of 2 -to- 1 or 3 -to-1 indicates an acceptable fit between the hypothetical model and the sample data (Carmnines \& McIver,1981). Because the sample sizes in our analyses were too large for the $\chi^{2}$ test, the $\chi 2$ measure was not used as the sole indicator of fit. The GFI measures the relative amount of variance and covariance in the sample covariance matrix that is jointly explained by the population covariance matrix. The AGFI is the adjusted version of GFI, where the degrees of freedom of a model and the number of unknown variables are taken into consideration for adjustment. Both GFI and AGFI values fall between 0 and 1 , with values exceeding 0.90 considered acceptable and being indicative of good fit $(\mathrm{Hu}$ \& Bentler, 1999). RMR indicates the square root of the mean of the squared discrepancies between the implied and observed covariance matrices (Schumacker \& Lomax, 2004), so a smaller RMR value represents a better fit, and a value of 0 represents a perfect fit. An RMR value smaller than 0.05 indicates good fit. As with the GFI, comparative indices of fit measure the proportionate improvement in fit by comparing a target model with a baseline model. A null model in which all the observed variables are uncorrelated is the most typically used baseline model. CFI values ranged from 0 to 1 , whereas a CFI value above 0.90 was considered a good fit. NFI analyses the discrepancy between the chi square value of the hypothesised model and the chi square value of the null model. NFI greater than or equal to 0.9 indicates acceptable model fit. The chi square was significant $(\chi 2(2)=33.59, \mathrm{p}=0.00)$ in the measurement model of HRM practices, but other fit indices indicated an acceptable fit with the data (GFI $=0.94, \quad A G F I=0.72$, $\mathrm{RMR}=0.05$, NFI=0.94, CFI=0.94). The chi square was also significant $(\chi 2(2)=13.26, p=0.00)$ in the measurement model of service performance, but other fit indices indicated 
an acceptable fit with the data (GFI=0.98, AGFI=0.89, $\mathrm{RMR}=0.01, \mathrm{NFI}=0.98, \mathrm{CFI}=0.98)$.

Table 2 presents the means, standard deviations, and itemscale correlation matrix used for the analysis. The item-scale correlation matrix examines the item internal consistency and the equality of item-scale correlations. For the Pearson correlation coefficient ( $\mathrm{r}$ ), item internal consistency is considered substantial and satisfactory if an item correlates to 0.4 and above with its hypothesised scale (Ware, Brook,
Davies Avery, Williams, Stewart, Rogers, Donald \& Johnston, 1980). In Table 2, each HRM practice indicates a positive relationship between all the other HRM practices. Similarly, each service performance item indicates a positive relationship between all the other service performance items. The results indicate that items are substantially linearly related to the total scale score, and items in a scale contribute roughly equal proportions of information to the total score of its hypothesised scale.

Table 2: Means (M), standard deviations (SD), and the correlation matrix used in the hypothesised model of HRM practices and service performance $(n=276)$

\begin{tabular}{llllllllll}
\hline Measure & $\mathrm{M}$ & $\mathrm{SD}$ & \multicolumn{1}{c}{1} & 2 & 3 & 4 & 5 & 6 & 7 \\
\hline HRPR1 & 4.36 & 0.88 & 1 & & & & & & \\
HRPR2 & 4.39 & 0.86 & $0.83^{* *}$ & 1 & & & & \\
HRPR3 & 4.04 & 0.76 & $0.57^{* *}$ & $0.55^{* *}$ & 1 & & & \\
HRPR4 & 3.99 & 0.91 & $0.46^{* *}$ & $0.47^{* *}$ & $0.55^{* *}$ & 1 & & \\
SEP1 & 3.37 & 0.73 & $0.21^{* *}$ & $0.19^{* *}$ & 0.01 & 0.10 & 1 & & \\
SEP2 & 3.60 & 0.62 & 0.05 & 0.04 & -0.10 & 0.08 & $0.67^{* *}$ & 1 & \\
SEP3 & 3.45 & 0.73 & $0.13^{*}$ & $0.12^{*}$ & -0.01 & 0.10 & $0.82^{* *}$ & $0.56^{* *}$ & 1 \\
SEP4 & 3.28 & 0.75 & $0.13^{*}$ & 0.06 & -0.03 & 0.11 & $0.64 * *$ & $0.54^{* * *}$ & $0.64^{* *}$ \\
\hline
\end{tabular}

$* \mathrm{p}<0.05, * * \mathrm{p}<0.01, * * * \mathrm{P}<0.001$

Note: HRPR1 = recruitment and selection, HRPR2 = training and development, HRPR3 = rewarding quality, and HRPR4 = retention; SEP1 = competency, $\mathrm{SEP} 2=$ service attitude, SEP3 = prompt service, and SEP4 = provision of information.

Table 3 shows the overall fit indexes of our model. It shows that our model produced good results at the $\chi 2 /$ d.f., GFI, RMR, AGFI, CFI, and marginal fitness levels for the indexes of NFI. We concluded that our findings had reached an acceptable level and could be used to explain our hypotheses. The theoretical model used in this study integrates human resource management and service performance models. HRM practices are independent variables, and service performance practices are dependent variables. The full SEM fit well : $\chi 2(18)=46.57$, GFI $=0.96$, $\mathrm{RMR}=0.03$, AGFI=0.92, NFI=0.96, and $\mathrm{CFI}=0.98$. As a result, the model fit corresponded with the estimation standards of an SEM, and the reliability and validity of this study were judged to be satisfactory. The structured factors used in this study are shown in Figure 2. The structured factor of HRM for service performance was significant at 0.19 ( $\mathrm{p}<0.01)$. Therefore, HRM practices have significant positive impacts on the service performance of student interns. The results correspond with the findings of previous studies (e.g., Chand, 2010; Wright, Gardner \& Moynihan, 2003).

Table 3: Overall model fit indices

\begin{tabular}{lcc}
\hline \multicolumn{1}{c}{ Fit index } & Scores & Criterion \\
\hline$\chi 2 /$ d.f. & 2.59 & $(\chi 2) / \mathrm{df}<3$ \\
Goodness of Fit Index (GFI) & 0.96 & GFI $>0.90$ \\
Adjusted Goodness of Fit Index (AGFI) & 0.92 & AGFI $>0.90$ \\
Root Mean Square Residual (RMR) & 0.03 & RMR $<0.05$ \\
Normed Fit Index (NFI) & 0.96 & NFI $>0.90$ \\
Comparative Fit Index (CFI) & 0.98 & CFI $>0.90$ \\
\hline
\end{tabular}

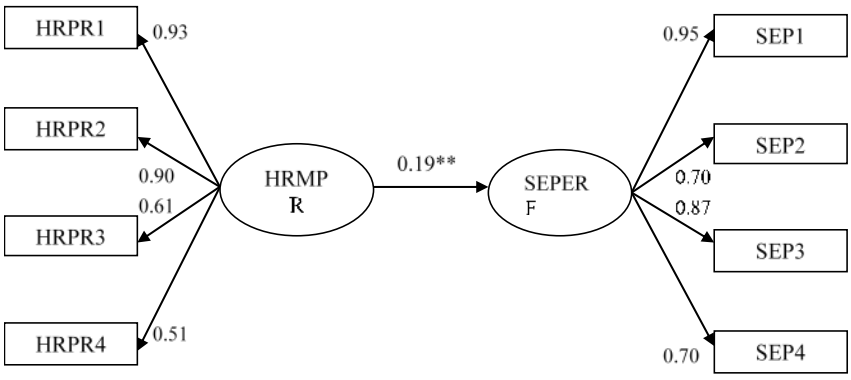

Figure 2: Path model of HRM practices and service performance with path coefficients

\section{Multiple regression analysis}

To examine the effect of HRM practices on each service performance of student interns, multiple regression analysis was performed with the constituent components of HRM practices (recruitment and selection, training and development, rewarding quality, and retention) as the predictor variables. The service performance measures, including prompt service, service attitudes, provision of information, and competency, were used as the dependent variable. A total of four multiple regressions were conducted, and the $\mathrm{R}^{2}$ for each regression was significant. The results are presented in Table 4. 
Table 4: Multiple regression analyses of HRM practices and service performance ( $n=276)$

\begin{tabular}{|c|c|c|c|c|}
\hline \multirow[t]{3}{*}{ Predictor variables } & \multicolumn{4}{|c|}{ Dependent variable } \\
\hline & SEP1 & SEP2 & SEP3 & SEP4 \\
\hline & Beta value & Beta value & Beta value & Beta value \\
\hline HRPR1 & $0.22 *$ & 0.11 & 0.15 & $0.29 * *$ \\
\hline HRPR2 & 0.09 & 0.01 & 0.04 & -0.15 \\
\hline HRPR3 & $-0.20 * *$ & $-0.26 * * *$ & $-0.18 *$ & $-0.20 *$ \\
\hline HRPR4 & 0.07 & $0.17 *$ & 0.11 & $0.15^{*}$ \\
\hline $\mathrm{R}^{2}$ & $6.79 \%$ & $4.41 \%$ & $3.69 \%$ & $5.11 \%$ \\
\hline F value & $4.94 * * *$ & $3.12 *$ & $2.60 *$ & $3.65 * *$ \\
\hline
\end{tabular}

$* \mathrm{p}<0.05, * * \mathrm{p}<0.01, * * * \mathrm{P}<0.001$

Note: HRPR 1 = recruitment and selection, HRPR2 = training and development, HRPR3 = rewarding quality, and HRPR4 = retention; SEP1 = competency, SEP2 = service attitude, SEP3 = prompt service, and SEP4 = provision of information.

\section{Discussion}

According to the results of our analysis, recruitment and selection practices have significant positive impacts on the competency and provision of information of student interns; retention has significant positive impacts on student interns' service attitude and provision of information. However, training and development revealed no significant effects on the service performance of student interns. Moreover, rewarding quality had significant negative effects on student interns' service performance. The following sections further discuss the effect of HRM practices on the service performance of student interns.

\section{Recruitment and selection}

The process of recruiting and selecting through industry internships provides a good opportunity for the hotel industry to come into contact with prospective employees who suit their organisations. Our findings indicate that recruitment and selection practices have significant positive effects on the competency and provision of information by student interns. In addition to demonstrating the importance of recruitment and selection practices for student interns, the results indirectly revealed the hidden anxiety of students enrolled in hospitality higher education. Selecting employees who have completed hospitality "higher" education no longer guarantees a high-quality workforce. The widespread establishment of hospitality programs in different academic institutions has led to uneven quality among students (Teng, 2006). Therefore, organisations need to recruit individuals with appropriate skills and attitudes (Bou \& Beltrán, 2005). Ingelssona et al. (2012) suggested that the selection strategy seems to be both unapplied and underestimated when working with TQM. TQM requires HR professionals to work closely with line managers or interns' mentors, where HRM plays a more decentralised role. The process of recruitment and selection differs from one co-op organisation to another. Some hotels hold internship orientations in schools and select students with appropriate ability, trainability, and commitment. Some hotels deliver recruitment information to academic institutions and allow interested students to apply for the internship by themselves. Human resource planning plays a strategic role in ensuring recruitment and selection of student interns whose goals and values fit with the TQM philosophy, and whose traits will be suited to a flexible and team-based hospitality environment. Candidate interns indicate a willingness to receive new training and to expand job roles, try new ideas and problem-solving techniques, work patiently in teams within and across departments, and be enough of a team player to be evaluated and rewarded on a team basis (Clinton, Williamson \& Bethke, 1994). Successful recruitment and selection of student interns with the proper knowledge, abilities, skills, and attitudes compatible with a TQM philosophy can be a driving force supporting continued program effectiveness of organisations.

\section{Training and development}

It has been widely argued that training is essential if the principles of TQM are to be successfully implemented (Mathews, Ueno, Kekale, Repka, Periera \& Silva, 2001). However, our analysis indicated that training and development practices have no significant effect on the service performance of student interns. These results differ from the results of previous studies (e.g., Li, Yang \& Wu, 2008). Partlow (1996) indicated that those hotel managers who apply the principles of TQM will perceive training as a more significant activity and put greater emphasis on quality as a component of their training efforts. In developing TQM training and development systems, efforts should be aimed at an integrated approach to the instruction process. HR professionals must decide what knowledge and skills must be taught to student interns and how to implement with the time constraint of internship period. In addition, the objectives of training and development should be directed towards helping student interns understand the principles of TQM. Student interns will need to understand how TQM is to be achieved or maintained; the interns also need to comprehend their roles in implementing the mission and vision of the organisation at which they train.

\section{Rewarding quality}

Our findings indicate that the quality of a reward has a significant negative effect on student interns' service performance. From a pragmatic standpoint, the rewards offered by international hotels are not what student interns want or expect. The philosophy of TQM emphasises group effectiveness and responsibility for an entire process. A TQM-based rewarding approach is a team effort and for all employees, including student interns. However, hotel 
industry entrepreneurs view rewards for student interns as a fixed cost; an increase in benefits to interns will result in pay cuts for the interns. In addition, many full-time employees have work experience and qualifications that are inferior to those of student interns. However, student interns do not have access to the benefits that are granted to full-time employees such as shared tips, participation in the year-end party, paid leave, employee bonuses, free employee meals, or employee tours. International hotels do not equitably transfer the reward system enjoyed by full-time employees to student interns, and the result is that the reward quality has negative effects on the service performance of student interns. Overall, the most rewarding currently utilised practice for student interns is the use of the part-time employee standard. Few employers design rewarding practices specifically for student interns. In rewarding team efforts for quality improvement, supervisors can inform both student interns and full-time employees about TQM achievements, and can identify opportunities to feature outstanding accomplishments of team members who deserve rewards. Allen and Kilmann (2001) indicated that the use of extrinsic reward practices, including profit sharing, gain sharing, employment security, and comp time, exhibited a significantly positive moderating effect on the relationship between TQM and perceived firm performance. To create quality internship experiences, it is vital that internship organisations and students have comparable perceptions of and expectations for the internship experience (Beggs, Ross \& Goodwin, 2008). Zelnik, Maletič, Maletič and Gomišček (2012) also stressed the significance of acknowledgement of employee expectations. These results may encourage hotel professionals to reflect on what student interns really need and expect and to utilise reward practices that specifically complement TQM-based strategies.

\section{Retention}

The results of this study indicate that retention practices have significant positive effects on the service attitudes of student interns. These results support the findings of Kinicki, Carson and Bohlander (1992), who determined that HRM activities have positive impacts on employee attitudes. Previous studies have proven that job satisfaction and employee retention have a strong relationship with work performance (Harter, Schmidt \& Hayes, 2002). In the concept of TQM, it is believed that employees who possess a high level of satisfaction will have strong motivation and good morals and will be effective and efficient in their work performance (Eskildsen \& Dahlgaard, 2000). Finding employees who are enthusiastic and well suited to an organisation's culture is the biggest challenge for the hospitality industry (Jauhari \& Manaktola, 2007). Simons and Hinkin (2001) further contended that employee turnover is more costly for luxury hotels than for lower budget hotels, due to the more sophisticated operating and training systems of luxury hotels. Industry internships offer hotels a golden opportunity to test out potential employees before hiring them. These results further provide hotel professionals with useful information, indicating that TQM is more likely to lower turnover rates of employees because it helps to induce job satisfaction (Huselid, 1995; Cho, Woods, Jang \& Erdem, 2006). Further, satisfied employees will also be more committed to continuously improve and to improve quality of service.

\section{Conclusions and implications}

Our findings, which are compatible with TQM philosophy, provide information that is relevant to both hospitality educators and hotel industry professionals. The SEM offers a strong foundation for internship development and implementation. HRM practices, including recruitment and selection, training and development, rewarding quality, and retention, can serve as references for hotel industry professionals to enhance the service performance of student interns. HRM professionals are better able to take charge of these important functions as they relate to a TQM strategy. Hotel industry professionals should develop team-based bonus systems for student interns and, within their resource constraints, appropriately transfer the quality rewards available to full-time employees to student interns. Furthermore, a system to encourage retention could be developed whereby seniority earned by student interns could translate into a full-time position.

The finding that training and development practices had no significant effects on the service performance of student interns is important but not surprising. Well-educated and well-trained students, especially those trained in hospitality higher education programs, meet the basic expectations of the hotel industry. The findings indicate the areas that hospitality higher education should emphasise in preparing students for their future careers. Therefore, curriculum planners should assess whether students possess work-ready competencies and should provide a series of pre-internship learning experiences to ensure that these competencies are developed. After completing industry internships, students must return to school to continue their studies. The results of our research also offer academic institutions information that can be used to strengthen unsatisfactory service performance of student interns during their last year of school.

Our results may offer initial insights that will help hospitality educators redesign their curricula, taking HRM practices into consideration. The process of initial recruitment and selection could be extended and divided into two stages. Students who are not selected in the first stage should undergo additional competency training by faculty in preparation for the second stage. The hotel industry could assign hospitality professionals to reside at a training restaurant or hotel and offer orientation training and on-the-job training during on-campus internships (preinternships). Furthermore, line mangers and intern mentors who are more familiar with the students could assist the hotels in the process of recruitment and selection. Through resource-sharing and assistance within the industry, academic institutions can increase the efficiency of training programs and ensure that the quality of service provided by students meets the requirements of the industry. After 
students complete industry internships, academic institutions can provide them with career development courses to encourage students to commit to the hospitality industry after graduation. Post-internship programs should also be planned. Students who have completed industry internships may be appointed leaders at practice restaurants or hotels and could thereby apply the experience they acquired during their industry internships to develop their management skills. Post-internship programs could enable hospitality students to maintain their work proficiency and keep abreast of developments in their field.

The changing flexible labour structure creates a new vision in the philosophy of the hotel industry in the Asia Pacific region. Companies have to excel in their business practices in order to compete in global markets. The role of HRM in leading organisational excellence was well documented. The results of this study lay the groundwork for the development of TQM-based HRM practices for student interns in the hotel industry. The application of HRM strategies, techniques, and tools to student interns enabled the hotel practitioners to achieve quality performance in managing business. The strong foundation for internship development and implementation was also proffered as the solution to making higher education more relevant to the needs of society. Academic institutions and the hotel industry need to recognise that they are as a system of interrelated parts. Through continuous improvement and management by objective and facts, educators and industry practitioners can establish a new cooperative relationship. In the long run, a collaboration utilising HRM practices developed by hotelindustry professionals and curriculum design from hospitality academic institutions may establish and manage total quality initiatives in the hotel industry and achieve the goals of hospitality higher education.

However, some limitations of this study remain. Overall, service performance could be susceptible to the influence of personality traits. In future research, the personality traits of student interns and other internship factors can be analysed as factors that affect the service performance of student interns. In addition, the respondents come from different department where there exist different perceptions about perceived importance of HRM practices and perceived service performance. Finally, this model has only been tested in the international hotel industry. Future studies could also examine different levels of the hotel industry to increase the quality and validity of the results.

\section{References}

Anderson, J. \& Gerbing, D.W. 1988. 'Structural equation modeling in practice: A review and recommended two-step approach', Psychological Bulletin, 103(3): 411-23.

Allen, R.S. \& Kilmann, R.H. 2001. 'The role of the award system for a Total Quality Management based strategy', Journal of Organizational Change, 14(2): 110-31.

Babu, K.S., Naresh, G. \& Kumar, B.R. 2011. 'Integrating HR practices in a TQM environment', The International Journal's Research Journal of Social Science \& Management, 1(1): 74-81.
Beggs, B.A., Ross, C.M. \& Goodwin, B. 2008. 'A comparison of student and practitioner perspectives of the travel and tourism internship', Journal of Hospitality, Leisure, Sport and Tourism Education, 7(1): 31-9.

Bou, J. \& Beltrán, I. 2005. 'Total quality management, highcommitment human resource strategy and firm performance: An empirical study', Total Quality Management \& Business Excellence, 16(1): 71-86.

Carmines, E.G. \& McIver, J.P. 1981. Analyzing models with unobservable variables. In Bohrnstedt, G.W. \& Borgatta, E.F. (Eds.). Social measurement: Current issue. Beverly Hills, CA: Sage Publications.

Chand, M. 2010. 'The impact of HRM practices on service quality, customer satisfaction and performance in the Indian hotel industry', The International Journal of Human Resource Management, 21(4): 551-66.

Cho, S., Woods, R.H., Jang, S.C. \& Erdem, M. 2006. 'Measuring the impact of human resource management practices on hospitality firms' performances', International Journal of Hospitality Management, 25(2): 262-77.

Clinton, R.J., Williamson, S. \& Bethke, A.L. 1994. 'Implementing total quality management: The role of human resources management', SAM Advanced Management Journal, 59(2): 10-6.

Dahlgaard-Park, S.M. 2012. 'Core values - The entrance to human satisfaction \& commitment', Total Quality Management \& Business Excellence, 23(2): 125-40.

Eskildsen, J.K. \& Dahlgaard, J.J. 2000. 'A causal model for employee satisfaction', Total Quality Management, 11(8): 108194.

Hansen, H., Sandvik, K. \& Selnes, F. 2003. 'Direct and Indirect effects of commitment to a service employee on the intention to stay', Journal of Service Research, 5(4): 356-68.

Harter, J.K., Schmidt, F.L. \& Hayes, T.L. 2002. 'Business-unitlevel relationship between employee satisfaction, employee engagement, and business outcomes: A meta- analysis', Journal of Applied Psychology, 87(2): 268-79.

Hu, L. \& Bentler, P. 1999. 'Cut off criteria for fit indices in covariance structure analysis: conventional criteria versus new alternatives'. Structural Equation Modeling, 6(1): 1-55.

Huselid, M.A. 1995. 'The impact of human resource management practices on turnover, productivity, and corporate financial performance', Academy of Management Journal, 38(3): 635-72.

Ingelssona, P., Erikssona, M. \& Liljaa, J. 2012. 'Can selecting the right values help TQM implementation? A case study about organisational homogeneity at the Walt Disney Company', Total Quality Management \& Business Excellence, 23(1): 1-11.

Jago, L.K. \& Deery, M. 2004. 'An investigation of the impact of internal labour markets in the hotel industry', The Service Industries Journal, 24(2): 118-29. 
Jauhari, V. \& Manaktola, K. 2007. 'Comparison of internship experiences in food service firms in India and UK', Journal of Foodservice Business Research, 9(2/3): 187-206.

Joreskog, K. 1993. Testing structural equation models. In Bollen, K.A. \& Long, J.S. (Eds.). Testing structural equation models. Newbury Park, CA: Sage Publications.

Kanji, G.K. \& Tambi, A.M. 1999. 'Total quality management in UK higher education institutions', Total Quality Management, 10(1): 129-53.

Kinicki, A.J., Carson, K.P. \& Bohlander, G.W. 1992. 'Relationship between an organization's actual human resource efforts and employee attitudes', Group and Organization Management, 17(2): $135-52$.

Kusluvan, S. \& Kusluvan, Z. 2000. 'Perceptions and attitudes of undergraduate tourism students towards working in the tourism industry in Turkey', Tourism Management, 21(3): 251-69.

Li, J.M., Yang, J.S. \& Wu, H.H. 2008. 'Improving service quality and organisation performance through human resource practices. A case study', Total Quality Management \& Business Excellence, 19(9): 969-85.

Liao, H. \& Chuang, A. 2004. 'A multilevel investigation of factors influencing employee service performance and customer outcomes', Academy of Management Journal, 47(1): 41-58.

Lucas, R. 2004. Employment Relations in the Hospitality and Tourism Industries. London: Routledge.

Lucas, R., Marinova, M., Kucerova, J. \& Vetrokova, M. 2004. 'HRM practice in emerging economies: A long way to go in the Slovak hotel industry', International Journal of Human Resource Management, 15(7): 1262-79.

Mathews, B., Ueno, A., Kekale, T., Repka, M., Periera, Z. \& Silva, G. 2001. 'Quality training: needs and evaluation-findings from a European survey’, Total Quality Management, 12(4): 483-90.

McMahon, U. \& Quinn, U. 1995. 'Maximizing the hospitality management student work placement experience: A case study', Education + Training, 37(4): 13-7.

Nickson, D. 2007. Human Resource Management for the Hospitality and Tourism Industries. Oxford: ButterworthHeinemann

Partlow, C.G. 1996. 'Human resources practices of TQM hotels', Cornell Hotel and Restaurant Administration Quarterly, 37(5): 6777.

Schumacker, R.E. \& Lomax, R.G. 2004. A beginner's guide to structural equation modeling. Mahwah, NJ: Lawrence Erlbaum.

Sheng, H.T. \& Lin, Y.C. 2004. 'Promoting service quality in tourist hotels: The role of HRM practices and service behaviour', Tourism Management, 25(4): 471-81.

Simons, T. \& Hinkin, T. 2001, 'The effect of employee turnover on hotel profits: A test across multiple hotels', Cornell Hotel and Restaurant Administration Quarterly, 42(4): 65-9.
Sureshchandar, G.S., Rajendran, C. \& Anantharaman, R.N. 2001. 'A conceptual model for total quality management in service organizations', Total Quality Management, 12(3): 343-63.

Teng, C.C. 2006. 'What do they really think? A study of hospitality students' learning satisfaction in Taiwan', Journal of Hospitality and Home Economics, 3(2): 153-67.

Ugboro, I.O. \& Obeng, K. 2000. 'Top management leadership, employee empowerment, job satisfaction, and customer satisfaction in TQM organizations: an empirical study', Journal of Quality Management, 5(2): 247-72.

Ware, J.E., Brook, R.H., Davies-Avery, A., Williams, K.N., Stewart, A.L., Rogers, W.H., Donald, C.A. \& Johnston, S.A. 1980. Conceptualisation and measurement of health for adults in the health insurance study: Vol. 1, Model of Health and Methodology. Santa Monica, CA: RAND Corporation.

Wilkinson, A., Redman, T., Snape, E. \& Marchington, M. 1998. Managing with Total Quality Management: Theory and Practice. London: Macmillan Press Ltd.

Wright, P.M., Gardner, T.M. \& Moynihan, L.M. 2003. 'The impact of HR practices on the performance of business units', Human Resource Management Journal, 13(3): 21-36.

Zelnik, M., Maletič, M., Maletič, D. \& Gomišček, B. 2012. 'Quality management systems as a link between management and employees', Total Quality Management \& Business Excellence, 23(1): 45-62 
